\title{
IMPROVED PRODUCTION OF TIGER SHRIMP (Penaeus monodon) THROUGH PROBIOTICS APPLICATION
}

\author{
Irsyaphiani Insan, Endhay Kusnendar Kontara, and Raden Roro Sri Pudji Sinarni Dewi \\ Centre for Aquaculture Research and Development
}

(Received 21 October 2014; Final revised 17 September 2015; Accepted 10 November 2015)

\begin{abstract}
The study was carried out in Brebes District, the North coast of Java. Tiger shrimp farming in Indonesia, particularly in this area faced some problems which caused by improper pond preparation, disease, and low seed quality. Probiotic was applied in pond to solve this problem. The aim of this study was to evaluate the production of tiger shrimp in ponds with probiotic applications. Six experimental ponds (each measuring $0.5 \mathrm{ha}$ ) were selected of which three were probiotic ponds and three were controlled. Tiger shrimp postlarvae (PL-30) were stocked at density of four shrimps $/ \mathrm{m}^{2}$. Tiger shrimps were reared for three months. Shrimps were fed by commercial pellet. In the first month, shrimp were fed about $7 \%-5 \%$ of the total biomass; in the second months, $3.5 \%-3 \%$ of the total biomass; and in the third month, $2.5 \%-2 \%$ of the total biomass. The treatments in this study were the application of probiotics with concentration of $3 \mathrm{mg} / \mathrm{L}$ that were given every five days and control (without probiotics). The results showed the rearing period was 92 \pm 6 days in probiotic ponds and $76 \pm 16$ days in controlled pond. The shrimp in controlled pond should be harvest earlier caused by the high mortality. The average final weight was $16.2 \pm 0.7 \mathrm{~g}$ in probiotic pond and $15.6 \pm 1.9 \mathrm{~g}$ in controlled pond. The survival rate was $64.13 \pm 12.63 \%$ in probiotic pond and $44.17 \pm 14.15 \%$ in controlled pond. Production was $208 \pm 46 \mathrm{~kg} /$ pond/cycle in probiotic pond and $123 \pm$ $6 \mathrm{~kg} / \mathrm{pond} / \mathrm{cycle}$ in controlled pond. The result showed that probiotic plays an important role in maintaining water quality parameters and health management as well as increases the survival of shrimp.
\end{abstract}

KEYWORDS: Penaeus monodon, productivity, probiotic

\section{INTRODUCTION}

Tiger shrimp (Penaeus monodon) is a priority commodity, and designated as industry commodity in Indonesia. Currently, the total area of brackishwater pond in Indonesia reached approximately 450,000 hectares, of which nearly $90 \%$ of the existing ponds are traditionally managed for tiger shrimp, vannamei shrimp, milkfish, and so on. Since the early 1990s, shrimp culture faced some problems, caused by the attack of various diseases such as White Spot Syndrome Virus (WSSV), Taura Syndrome Virus (TSV), and so on. The failure of tiger shrimp culture happened either on extensive, semi-intensive or intensive system. Several attempts have been made to increase the production of shrimp in Indonesian, such as in 1999, the Ministry of Marine Affairs and Fisheries of Indonesia, had introduced vannamei shrimp

\# Correspondence: Centre of Aquaculture Research and Development. Jl. Ragunan 20, Pasar Minggu, Jakarta Selatan 12540, Indonesia. Tel.: + (021) 7805052

E-mail: aniinsan@yahoo.com
(Litopenaeus vannamei) from Latin America to Indonesia. This effort was quite successful in increasing the production of shrimp and vannamei shrimp culture rapidly grew in some areas. However, lately, vannamei shrimp culture in Indonesia is also experiencing problems due to disease, which affects the national shrimp production. Various problems are often encountered in vannamei shrimp culture including lack of availability of good quality seeds and free from specific pathogen, development of various diseases such as WSSV, TSV, IHHVN, Mio, Vibrio, high feed prices, and environmental degradation. These things cause low productivity due to errors in the management of aquaculture, especially the arrangement of pond area (Pantjara et al., 2007).

The application of probiotics in shrimp culture can improve environmental quality and overcome disease problems. The role of probiotic is controlling pathogens with varying mechanisms (Balcazar et al., 2006). The application of probiotic in shrimp medium can serve as a complementary source of feed or contribution to the digestive system and is expected to 
reduce the population of pathogenic bacteria, by producing anti-bacterial ingredients, such as bacteriocins, lysozyme, protease, siderophore, hydrogen peroxide or organic acids (Verschuere et al., 2000). Probiotics also play a role to enhance the immune response, growth, antimutagenic, and anticarcinogenic (Wang, 2007). The application of probiotics in shrimp pond could improve quality of bottom sediments, especially in increasing the redox potential value (Gunarto et al., 2006) and improve water quality (Matiasi et al., 2002).

Brebes District is one area of shrimp culture development on the North coast of Java. The low production of shrimp in this area is due to improper pond preparation, disease, and poor quality seeds. Effort made to overcome this problem is through application of probiotics. RICA probiotic was used in this study. RICA probiotics produced by the Research Center for Coastal Aquaculture. The role of these bacteria are to improve water quality (decrease total organic matter, ammonia, and nitrite), and inhibit proliferation of pathogenic organisms, such as Vibrio harveyi and White Spot Syndrome Virus (WSSV). There are three types of RICA probiotic, those are Brevibacillus laterosporus (RICA-1), Serratia marcescens (RICA-2), and Pseudoalteromonas sp. (RICA-3) (Atmomarsono et al.,
2011). Atmomarsono et al. (2012) reported that rotation application of RICA-1 probiotics in the first month, then RICA-2 in the second month, and RICA3 (BL542) in the third month, in a traditional ponds, with stocking density of 2 shrimps $/ \mathrm{m}^{2}$ increased an average yield up to $220 \mathrm{~kg} / \mathrm{ha} / \mathrm{cycle}$ and the survival rate of approximately $30 \%$.

This research was aimed to evaluate the production of tiger shrimp in ponds with probiotic applications. It is expected that the application of probiotic could increase shrimp pond productivity.

\section{MATERIALS AND METHODS}

\section{Location and Time of Research}

The study was conducted in Randusanga Kulon Village, Subdistrict of Brebes, Brebes District, Central Java (Figure 1). Six ponds used were approximately 0.5 ha each. Shrimp culture was done for three months, from September to December 2013.

\section{Pond Preparation}

Pond preparation was done with standard procedures for traditional system which includes repairing pond construction, drying and processing of basic soil, liming, fertilizing, and pest control (WWF, 2011).

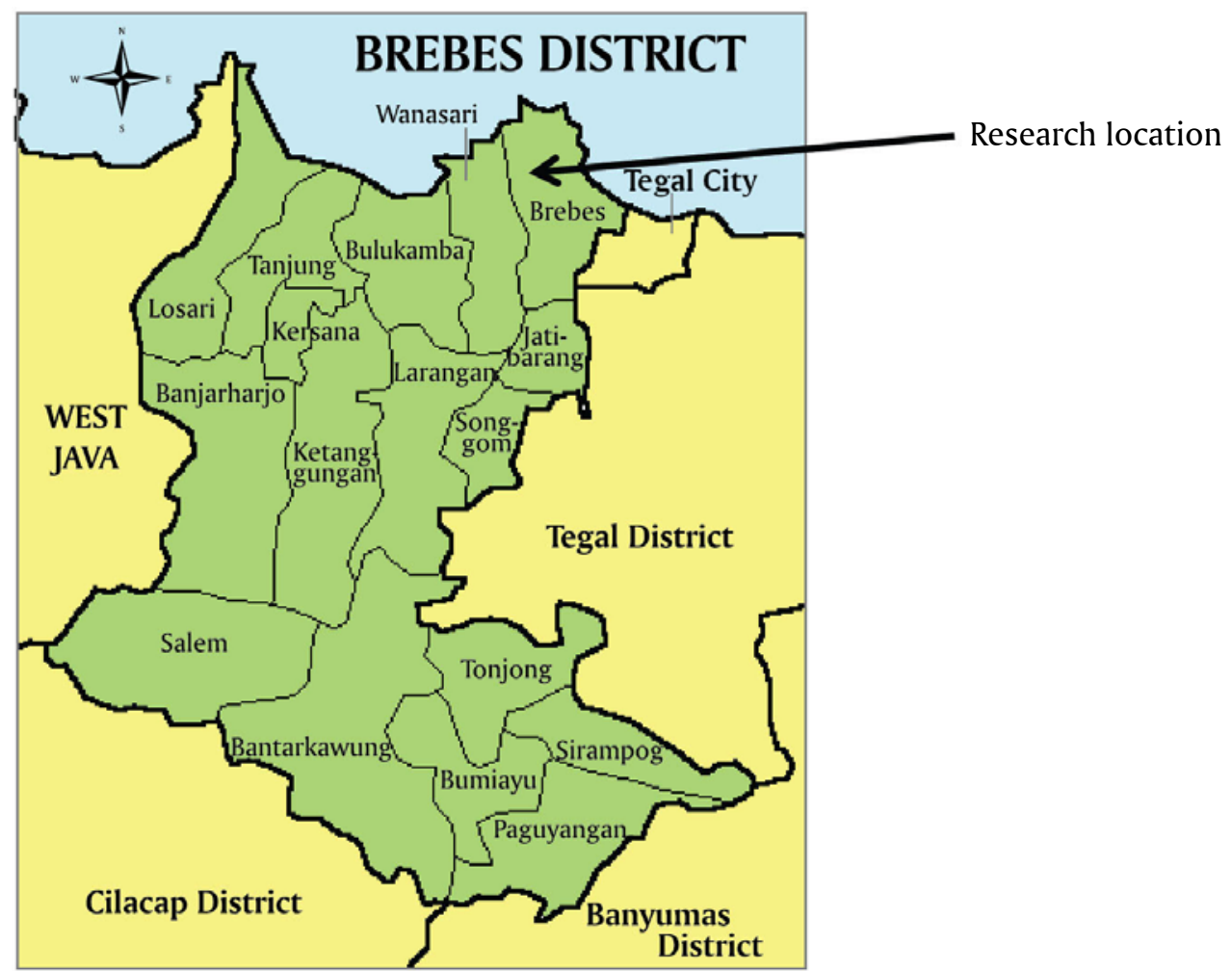

Figure 1. Research location in Randusanga Kulon Village, Subdistrict of Brebes, Brebes District, Central Java 


\section{Stocking of Tiger Shrimp Seed}

Stocking of tiger shrimps in ponds was done after plankton growth (1-2 weeks after fertilization), which was characterized by the green or brownishgreen color of water, with a density of $4 \mathrm{shrimp} / \mathrm{m}^{2}$. In this study, we used specific pathogen free (SPF) shrimps that were tested by PCR method. Seeds (30 days old of post larvae/PL-30) were obtained from shrimp hatcheries owned by Center for Development of Brackishwater Aquaculture in Jepara.

\section{Probiotic Application}

The treatments were: (A) the application of probiotics with dosage of $3 \mathrm{mg} / \mathrm{L}$ that were given every five days; and (B) control, i.e. without probiotics. Each treatment was repeated three times. In this study, we used probiotic RICA that was produced by the Research Institute for Coastal Aquaculture in Maros. Probiotic RICA contained Bacillus sp. (isolates of BT951, MY1112, and BL-542). Application of probiotics into the pond was done 1-2 weeks after the shrimp was stocked. Probiotic was applied in the pond by mixing/diluting the bacterial culture with a little of pond water, then being spread evenly onto the surface of the pond water. To obtain the optimal results, probiotic was applied by rotation system. The BT951 (RICA 1) was given four times at second or third week of rearing, then continued by MY1112 (RICA 2) that was applied 3-4 times, then continued by BL-542 (RICA 3) that was applied 3-4 times, and probiotic application was repeated again by BT-951 until harvest time.

\section{Tiger Shrimp Rearing}

Tiger shrimps were reared for three months. During rearing period, shrimps were fed by commercial pellets with composition: at the first month, the amount of feed as much as $7 \%-5 \%$ of the total biomass, in the second month of around $3.5 \%-3 \%$ of the total biomass and in the third month was $2.5 \%-2 \%$ of the total biomass. Shrimp weight was measured every two weeks to estimate shrimp biomass. The estimated biomass was used to calculate the daily ration. Fertilization and liming were repeated during rearing period. Liming was conducted twice a week by using $\mathrm{Ca}\left(\mathrm{MgCO}_{3}\right)_{2}$, as much as $3-10 \mathrm{mg} / \mathrm{L}$, depending on the total alkalinity and discoloration of daily water.

\section{Parameters}

Observations were conducted on some parameters such as growth, survival, production, productivity, water quality, and economic analysis. Growth, survival, production, and productivity were measured at the end of research. Water quality was monitored every two weeks.

\section{RESULTS AND DISCUSSION}

\section{Productivity of Tiger Shrimp Farming}

Productivity of tiger shrimp farming on probiotic pond and control are presented in Table 1. In this study, probiotic application did not affect shrimp growt but significanly affect shrimp survival and production. Differences between the rearing period in tiger shrimp ponds with probiotic application and control were caused by disease that were characterized by the appearance of white spots on the carapace and the gradual death. In the control treatment, harvesting was done earlier (76 \pm 16 days) to avoid higher mortality rate. In the probiotic treatment, shrimps were harvested at $92 \pm 6$ days of rearing. Application of probiotics could improve the tiger shrimp resistance on diseases that were characterized by higher survival rate. Bacillus sp. boost the tiger shrimp resistance against diseases by activating cellular and humoral defense system (Rangpipat et al., 2000).

Table 1. Comparison between rearing period (day), the final weight $(\mathrm{g})$, and the survival rate $(\%)$ of tiger shrimp in probiotic ponds and control

\begin{tabular}{lcc}
\hline \multirow{2}{*}{ Parameters } & \multicolumn{2}{c}{ Treatments } \\
\cline { 2 - 3 } & Probiotic & Control \\
\hline Rearing period (days) & $92 \pm 6$ & $76 \pm 16$ \\
Initial weight & $1.2 \pm 0.7$ & $1.2 \pm 0.7$ \\
Final weight (g) & $16.2 \pm 0.7$ & $15.6 \pm 1.9$ \\
SGR (g/day) & 0,03 & 0,04 \\
Survival rate (\%) & $64.13 \pm 12.63$ & $44.17 \pm 14.15$ \\
Production (kg/pond/cycle) & $208 \pm 46$ & $123 \pm 6$ \\
Productivity (kg/ha/cycle) & $417 \pm 93$ & $247 \pm 12$ \\
\hline
\end{tabular}


At the time of harvesting, the productivity of tiger shrimp reared in ponds with probiotic treatment was $70 \%$ higher than control. It showed that the application of probiotics were able to increase the survival rate. Nurbaya et al. (2009) reported that the application of probiotics in ponds with stocking density of 2 shrimp $/ \mathrm{m}^{2}$ in the case of WSSV, was able to prevent the disease, the production of shrimps was $81.4 \mathrm{~kg} / \mathrm{ha}$ and the survival rate was $30.9 \%$, higher compared with controls (19 kg/ha and $11.8 \%)$. At higher stocking density (6 shrimps $\left./ \mathrm{m}^{2}\right)$, application of probiotics combination (BL542 + BR931 + MY1112 + MR55 + BT950) within 12 weeks without aeration was able to generate survival and production of tiger shrimp as much as $86.1 \%$ and $568 \mathrm{~kg} / \mathrm{ha}$ (approximately $216 \%$ compared to control).

\section{Water Quality}

Salinity, temperature, dissolved oxygen, and $\mathrm{pH}$ are important water quality parameters considered during the study. Water quality parameters were found more suitable in probiotics ponds than in controlled ponds (Table 2) those matches with the report of Jiravanichpaisal et al. (1997). Maintenance of good water quality is essential for optimum growth and survival of shrimps. In this study, temperature, and water salinity in probiotic pond and control almost similar. The water temperature ranges from $29^{\circ} \mathrm{C}-35^{\circ} \mathrm{C}$ led to slow growth of shrimp. Optimum temperature for tiger shrimp growth is $25^{\circ} \mathrm{C}-30^{\circ} \mathrm{C}$ (Buwono, 1993). The water temperature was an important environmental factor in shrimp culture, because it directly affects metabolism, oxygen consumption, growth, molting, and survival. In general, the suddenly temperature changes affect the immune system of shrimp (Shailender et al., 2012). Salinity is an important parameter in maintaining optimum growth and survival of shrimps (Soundarapandian et al., 2010). The water salinity in rearing pond ranges from 33-45. Soundarapandian et al. (2010) recommended an ideal salinity range of 10-35 ppt for $P$. monodon culture. Even though, P. monodon is euryhaline aquatic species, it is comfortable when exposed to optimum salinity. At high salinity the shrimp grows slowly but remains healthy and resistant to diseases.

The dissolved oxygen content and $\mathrm{pH}$ in control pond is lower than probiotic pond. Dissolved oxygen value is $5.5-6.3 \mathrm{mg} / \mathrm{L}$ in probiotic pond and 2.1-3.2 in control pond. Value of $\mathrm{pH}$ is $7-9$ in probiotic pond and 5-7 in control pond. Soundarapandian et al. (2010) stated in their study that $\mathrm{pH}$ is one of the vital environmental characteristics, which affects the metabolism, and other physiological process of shrimps. Cheng et al. (2003) said that the optimum range of pH 7 to 8.5 should be maintained for maximum growth and production. The optimum range of dissolved oxygen is $5-7 \mathrm{mg} / \mathrm{L}$ (Kordi \& Tancung, 2007). In the cultivation environment, water quality in the pond bottom decreased due to the buildup of residual feed, feces, and dead algae. In this study, Bacillus sp. contained in RICA probiotics, contributed to improving water quality. Gram-positive bacteria have better ability than gram-negative bacteria to convert organic matter into $\mathrm{CO}_{2}$. During the production cycle, the high concentration of gram-positive bacteria in pond can minimize the formation of organic carbon in the form of particles and dissolved materials. RICA probiotic containing Bacillus sp. acted to fix the pond bottom by decomposing organic matter. In control pond, anaerobic conditions that were caused by lower oxygen content, led to increase levels of carbon dioxide and decrease in $\mathrm{pH}$. Management of aquaculture pond without causing stress to the shrimp is the right approach to get optimum yield (Srinivas et al., 2013). The application of Bacillus sp. could improve water quality, survival rate, growth, health status of juvenile tiger shrimp, and reduce the Vibrio pathogens (Dalmin et al., 2001).

\section{Economic Analysis}

The price of shrimp in the probiotic treatment ranged from $\mathrm{Rp} \mathrm{120,000-Rp} \mathrm{130,000} \mathrm{with} \mathrm{shrimp}$ size of $15.38-16.67 \mathrm{~g}$. While in the control treatment, shrimp prices ranging from Rp 35,000—Rp 130,000. The lower price in the control treatment was due to the smaller size at harvest time (13.33 $\mathrm{g}$ to $16.67 \mathrm{~g}$ ) as a result of early harvesting because of disease. Disease attack in this study, also led to lower production of shrimp in control treatment. Comparison of profit in probiotic treatment was Rp 22,325,467 while in the control treatment was Rp 9,112,700. Based on the results of economic analysis, application of probiotics increased profits by $145 \%$ (Table $3)$.

Table 2. Water quality during rearing period

\begin{tabular}{lccc}
\hline \multicolumn{1}{c}{ Parameters } & Probiotic & Control & Optimal (reference) \\
\hline Temperature $\left({ }^{\circ} \mathrm{C}\right)$ & $29-34$ & $29-35$ & $25-30$ (Buwono, 1993) \\
$\mathrm{pH}$ & $7-9$ & $5-7$ & $7-8.5$ (Cheng, 2003) \\
Salinity (ppt) & $33-45$ & $33-43$ & $10-35$ (Soundarapandian et al . 2010) \\
DO (mg/L) & $5.5-6.3$ & $2.1-3.2$ & $5-7$ (Kordi \& Tancung, 2007) \\
\hline
\end{tabular}


Table 3. Economic analysis of tiger shrimp farming in probiotic pond and control

\begin{tabular}{lcc}
\hline \multicolumn{1}{c}{ Parameters } & Probiotic pond & Control \\
\hline Production (kg/pond) & $208 \pm 46$ & $123 \pm 6$ \\
Shrimp price (Rp/kg) & $120,000-130,000$ & $35,000-130,000$ \\
Production cost (Rp/pond) & $4,191,200 \pm 636,046$ & $2,816,833 \pm 279,495$ \\
Income (Rp/pond) & $26,516,700 \pm 6,775,753$ & $11,916,667 \pm 6,379,720$ \\
Profit (Rp/pond) & $22,325,467 \pm 6,141,430$ & $9,112,700 \pm 6,111,401$ \\
\hline
\end{tabular}

\section{CONCLUSION}

Application of probiotics could improve the production of tiger shrimp in ponds up to $70 \%$. Profits obtained with application of probiotic reached 145\% higher compared to control.

\section{REFERENCES}

Atmomarsono, M., Muliani, Nurbaya, Susianingsih, E., Nurhidayah, \& Rachmansyah. (2011). Aplikasi bakteri probiotik RICA pada budidaya udang windu di tambak. Badan Penelitian dan Pengembangan Kelautan dan Perikanan, Balai Penelitian dan Pengembangan Budidaya Air Payau.

Atmomarsono, M., Tampangallo, B.R., Tompo, A., Muliani, Nurbaya, Nurhidayah, \& Susianingsih, E. (2012). Laporan Teknis Penelitian Tahun Anggaran 2012. Kegiatan penelitian kesehatan ikan dan lingkungan budidaya air payau. Sub Kegiatan Pengujian probiotik RICA pada budidaya udang windu. Balai Penelitian dan Pengembangan Budidaya Air Payau. Maros, 28 pp.

Balcazar, J.L., de Blas, I., Ruiz-Zarzuela, I., Cunningham, D., Vandrell, D., \& Muzquiz, J.L. (2006). The role of probiotics in aquaculture. Veterinary Microbiology, 114, 173-186.

Buwono, I.D. (1993). Tambak udang windu sistem pengelolaan berpola intensif. Kanisius. Yogyakarta.

Cheng, W., Su-Mei Chen, F.I. Wang, Pei-I Hsu, \& Liu, C.H. (2003). Effects of temperature, pH, salinity and ammonia on the phagocytic activity and clearance efficiency of giant freshwater prawn Macrobrachium rosenbergii to Lactococcus garvieae. Aquaculture, 219, 111-121.

Dalmin, G., Kathiresan, K., \& Purushothaman, A. (2001). Effect of probiotics on bacterial population and health status of shrimp in culture pond ecosystem. Indian Journal Experimental Biology, 39, 939-942.

Gunarto, Tangko, A.M., Tampangallo, B.R., \& Muliani. (2006). Budidaya udang windu (Penaeus monodon) di tambak dengan penambahan probiotik. J. Ris. Akuakultur, 1(3), 303-313.

Jiravanichpaisal, P., Chuaychuwong, P, \& Menasveta, P. (1997). The use of Lactobacillus sp. as the probiotic bacteria in the giant tiger shrimp (Penaeus monodon Fabricius). Poster session of the 2nd Asia-Pacific marine biotechnology conference and 3rd Asia-pacific conference on algal biotechnology. May, 1997. Phuket Thailand, p. 16.

Kordi, K., \& Tancung, A.B. (2007). Pengelolaan kualitas air dalam budidaya perairan. PT Rhineka Cipta. Jakarta.

Matiasi, H.B., Yusoff, F.M., Shariff, M., \& Azhari, O. (2002). Effects of commercial microbial products on water quality on tropical shrimp culture ponds. Asian Fisheries Sciences, 15, 239-248.

Nurbaya, Muliani, Nurhidayah, \& Atmomarsono, M. (2009). Laporan Teknis Penelitian Tahun Anggaran 2009. Aplikasi probiotik di tambak rakyat di Kabupaten Barru, Sulawesi Selatan. Balai Riset Perikanan Budidaya Air Payau. Maros, 12 pp.

Pantjara, B.E.A., Nessa, M.N., Monoarfa, W., \& Djawad, I. (2007). Dampak perbaikan pematang tambak tanah sulfat masam terhadap peningkatan produktivitas udang windu.J. Ris. Akuakultur, 2(2), 257-269.

Rengpipat, S., Rukpratanporn, S., Piyatiratitivorakul, S., \& Menasaveta, P. (2000). Immunity enhancement in black tiger shrimp (Penaeus monodon) by a probiont bacterium (Bacillus S11). Aquaculture, 191, 271-288.

Soundarapandian, P., Ramanan, V., \& Dinakaran, G.K. (2010). Effect of probiotics on the growth and survival of Penaeus monodon (Fabricius). Current Research Journal of Social Sciences, 2(2), 51-57.

Shailender, M., Suresh Babu, Ch., Srikanth, B., Bangarraju, P., Siva Krishna, G., \& Jayagopal, P. (2012). Effect of probiotics on growth and survival of Penaeus monodon (Fabricius, 1798) post larvae infected with swollen hindgut syndrome 
(SHG) with better management practices. Journal of Pharmacy and Biological Sciences, 3(4), 33-40.

Srinivas, R., Manjulatha, C., \& Ramesh Babu, K. (2013). Impact of probiotics on culture ponds of penaeid shrimp, at east coast of Andhra Pradesh, India. International Journal of Recent Scientific Research, 4(7), 1050-1055.

Verschuere, L., Rombaut, G., Sorgeloos, P., \& Verstraete, W. (2000). Probiotic bacterial as bio- logical control agents in aquaculture. Microbial Mol. Biol. Rev., 64(4), 655-671.

Wang, Y.B. (2007). Effect of probiotics on growth performance and digestive enzyme activity of the shrimp Penaeus vannamei. Aquaculture, 269, 259264.

WWF. (2011). Budidaya udang windu: tanpa pakan dan tanpa aerasi. Yayasan WWF - Indonesia, 26 pp. 